J. Clin. Chem. Clin. Biochem.

Vol. 26, 1988, pp. 623-626

(C) 1988 Walter de Gruyter \& Co. Berlin - New York

\title{
Study of the Ergothioneine Concentration in the Blood of Individuals with Diabetes Mellitus
}

\author{
By R. M. Epand, R. F. Epand
}

Department of Biochemistry, McMaster University Health Sciences Centre, Hamilton, Ontario, L8N $3 Z 5$ and

\section{S. C. Wong}

Hemoglobinopathy Laboratory, St. Joseph's Hospital, Hamilton, Ontario, L8N $4 A 6$ and Department of Pathology, McMaster University Health Sciences Centre, Hamilton, Ontario, L8N $3 Z 5$

(Received December 14, 1987/July 21, 1988)

Summary: Ergothioneine concentrations in the blood of 113 patients with diabetes mellitus and 22 nondiabetic individuals were measured by high performance liquid chromatography. There is no statistically significant difference between the mean ergothioneine concentrations of the diabetic and non-diabetic populations but there are several significant differences within the diabetic population. Male diabetics have a higher ergothioneine concentration than female diabetics. Type II diabetics have a higher ergothioneine concentration than type I diabetics. Diabetics receiving a higher insulin dose have higher ergothioneine concentrations. There was no correlation of ergothioneine concentration with the concentration of haemoglobin $A_{1}$ or with the number of years diabetic. It is suggested that zinc therapy may be beneficial for diabetics having a high concentration of blood ergothioneine.

\section{Introduction}

Ergothioneine is the betaine of thiolhistidine which is found ubiquitously in living organisms. It is thought to be biosynthesized only in molds (1), but to accumulate in many organisms as a result of its slow rate of degradation (2). Ergothioneine can be in bound form (3) in the plasma or liver, but is present in free form $(1-3)$ in erythrocytes and many-tissues. It has been reported that diabetic patients have a significantly higher concentration of ergothioneine in their erythrocytes $(0.127 \mathrm{~g} / \mathrm{l})$ than normal individuals $(0.096$ $\mathrm{g} / \mathrm{l})$, with $16 \%$ of diabetics exceeding the highest concentration $(0.177 \mathrm{~g} / \mathrm{l})$ found in normal individuals and reaching concentrations as high as $0.60 \mathrm{~g} / 1$ (4). This elevation of ergothioneine concentrations is not just a result of the diabetic state, since no rise in ergothioneine concentrations is observed in rats made diabetic with alloxan (5). However, depancreatized rats have decreased red blood cell ergothioneine, suggest- ing a relationship between pancreatic function and ergothioneine pharmacodynamics (5). Ergothioneine concentrations have also been associated with the formation of cataracts, since cataractous human lens has a lower ergothioneine content than normal lens (6).

The possible role of ergothioneine in health and disease has received little attention (7). One of the chemical properties of ergothioneine which suggests that it might have biological effects is its ability to form complexes with divalent metal ions (8), although it would generally bind less metal ions than glutathione (9). It has been suggested that the chelation properties of ergothioneine could be important in the development of diabetes mellitus (10). Trace metals can regulate insulin release (11) as well as having insulin-like action (12) in the whole animal. Several studies have shown effects of ergothioneine on biological systems both in vitro and in vivo. Ergothioneine inhibits the 
degradation of insulin by a liver extract (13). It inhibits the activity of polyphenol oxidases (8), papain (14) and the ATPase activity of myosin in the absence of divalent cations (14). Ergothioneine inhibits lipid peroxidation in mouse liver homogenates (15). It accelerates the oxidation of reduced nicotinamide adenine dinucleotide by metmyoglobin or methaemoglobin (16). Ergothioneine also accelerates lactate formation in red blood cells (17) and reduced the pentobarbital sleeping time and inhibited hepatic injury (18). Ergothioneine protects against cadmium-induced teratogenesis (19).

Because of the variety of biological effects that have been demonstrated for ergothioneine and because of the previous association that had been demonstrated between blood ergothioneine concentrations and diabetes mellitus (4), it was decided to investigate this relationship further. In the original work of Fraser, a colorimetric method based on the diazotization of ergothioneine was used (4). Recently, with the development of high performance liquid chromatography (HPLC) ${ }^{1}$, a more specific and sensitive method for the determination of ergothioneine became available (2). We have used HPLC methodology to determine ergothioneine concentrations, primarily in diabetics, and evaluated if there is a correlation between these concentrations and other indices such as age, sex, haemoglobin $\mathrm{A}_{1}\left(\mathrm{HbA}_{1}\right)$ concentrations and class of diabetes.

\section{Methods}

Human blood specimens, which had been taken for diagnostic purposes, were used. The blood samples were collected in vacutainers with EDTA as anticoagulant. Glycosylated haemoglobin $\left(\mathrm{HbA}_{1}\right)$ was determined by the Isolab microcolumn procedure (20). For ergothioneine determinations the blood samples were diluted $1: 3$ with distilled water, placed in a boiling water bath for 15 minutes and then centrifuged for 15 minutes at top speed in a clinical centrifuge. A measured aliquot of variable volume of the supernate was withdrawn and lyophilized. The dried residue was taken up in aqueous ethanol, volume fraction 0.5 , and filtered through a 0.2 micron Gelman Acro LC13 filter assembly. Twenty to $100 \mu \mathrm{l}$ were injected onto a $4 \times 300 \mathrm{~mm} \mu$ Bondapak $\mathrm{NH}_{2}$ column with a guard column containing Bondapak AX/Corasil (Waters Associates, Milford, MA). The column was eluted with acetonitrile and water $(80+20$ by volume). A Varian Model 5560 HPLC instrument, fitted with a UV-200 scanning detector and a Model 8085 auto sampler, was used. The detector was set at $258 \mathrm{~nm}$ (the absorbance maximum of ergothioneine), and the flow rate set at $1 \mathrm{ml} / \mathrm{min}$. Ergothioneine was eluted at about $18 \mathrm{~min}$ as a distinct peak, well resolved from other peaks in the chromatograms. After the complete elution of ergothioneine, the acetonitrile, water $(80+20$ by volume) mixture was run for an additional

1) Abbreviations used:

HPLC, high performance liquid chromatography,

$\mathrm{HbA}_{1}$, haemoglobin $\mathrm{A}_{1}$,

S.E.M., standard error of the mean.
15 minutes to wash the column. After a number of runs, the column was washed with acetonitrile in water, volume fraction 0.5 and/or with pure acetonitrile followed by re-equilibration with the acetonitrile, water $(80+20$ by volume). A standard curve with 0.1 to $2 \mu \mathrm{g}$ of ergothioneine (Sigma Chem. Co., St. Louis, MO) was made and found to be linear. This standard curve was used to calculate the amount of ergothioneine in our samples using the Varian $\mathbf{4 2 7 0}$ integrator. Quantitative recovery (>95\%) of ergothioneine from aqueous solutions or added to blood samples was found after boiling, lyophilizing and redissolving in aqueous ethanol, volume fraction 0.5 . Similar results were found by Mayumi et al. (2), after whose work our method was adapted.

Statistical analysis was performed on an IBM-PC computer using the PC Statistician software package (Human Systems Dynamics, Northridge, CA). Frequency distributions were first obtained. Ergothioneine concentrations for diabetics do not follow a normal distribution. Statistical significance was evaluated using the non-parametric Mann-Whitney $\mathrm{U}$ test for this group but the Student t-test for the non-diabetic population which showed a normal distribution. The precision of our ergothioneine determinations by HPLC is within $\pm 10 \%$.

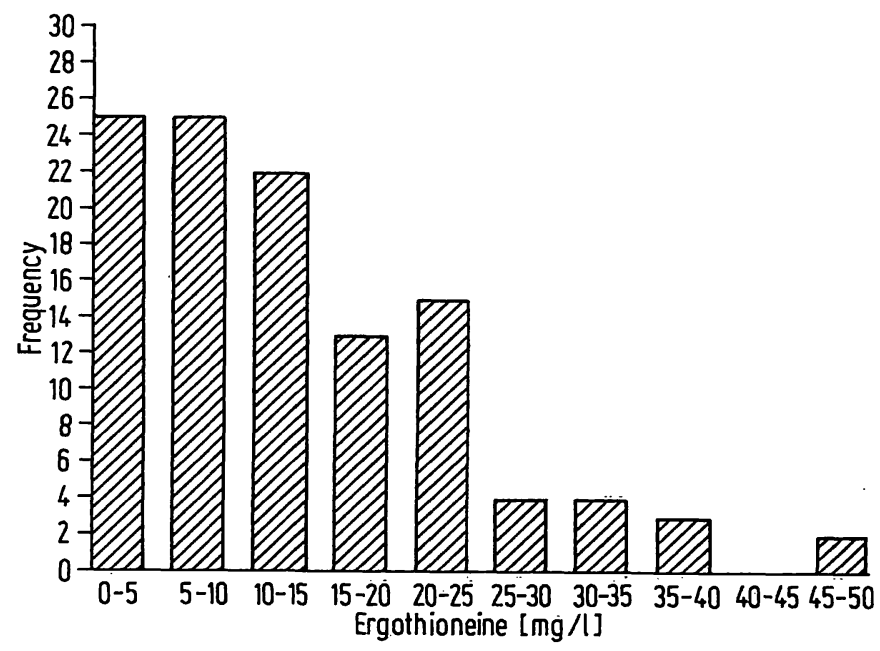

Fig. 1. Distribution of ergothioneine values in blood for the total diabetic population $(n=113)$.

\section{Results}

The frequency distribution of the blood ergothioneine concentrations of diabetic individuals shows a nonnormal distribution (fig. 1). Table 1 summarizes the results of our determinations of ergothioneine and the $\mathrm{HbA}_{1}$ concentrations for various categories of individuals. Although the difference between the ergothioneine concentrations in the total population of diabetics vs the non-diabetic population is not significant $(p>0.05)$, there are several statistically significant correlations within the diabetic population. The number of samples in several categories does not always add up to the total number of subjects tested, as some information, such as age, sex or type of diabetes, etc., was not available for some individuals. Diabetic males have significantly bìgher ergothioneine concentrations than diabetic females although there 
Tab. 1. Ergothioneine and $\mathrm{HbA}_{1}$ concentrations for various groups of individuals

\begin{tabular}{|c|c|c|c|c|c|}
\hline Subjects & $\mathbf{n}$ & $\begin{array}{l}\text { Average } \\
\text { age }\end{array}$ & $\begin{array}{l}\text { Ergothioneine } \\
\text { mg/l, mean } \pm \text { S.E.M. }\end{array}$ & $\mathrm{p}^{*}$ & $\begin{array}{l}\text { (Fraction of total) } \\
\mathrm{HbA}_{1} \text {, mean } \pm \text { S.E.M. }\end{array}$ \\
\hline All diabetics & 113 & 43 & $13.3 \pm 0.9$ & & $0.101 \pm 0.002$ \\
\hline $\begin{array}{l}\text { Diabetics, } 0 \\
\text { Diabetics, } 9\end{array}$ & $\begin{array}{l}58 \\
46\end{array}$ & $\begin{array}{l}46 \\
39\end{array}$ & $\begin{array}{l}15.6 \pm 1.4 \\
11.3 \pm 1.3\end{array}$ & 0.024 & $\begin{array}{l}0.102 \pm 0.003 \\
0.097 \pm 0.004\end{array}$ \\
\hline $\begin{array}{l}\text { Type I diabetics } \\
\text { Type II diabetics }\end{array}$ & $\begin{array}{l}65 \\
18\end{array}$ & $\begin{array}{l}42 \\
54\end{array}$ & $\begin{array}{l}12.0 \pm 1.2 \\
16.9 \pm 2.7\end{array}$ & 0.038 & $\begin{array}{l}0.099 \pm 0.003 \\
0.092 \pm 0.006\end{array}$ \\
\hline $\begin{array}{l}\text { Type I, } q \\
\text { Type II, } q\end{array}$ & $\begin{array}{r}27 \\
9\end{array}$ & $\begin{array}{l}36 \\
55\end{array}$ & $\begin{array}{l}11.6 \pm 2.1 \\
11.9 \pm 2.2\end{array}$ & $>0.05$ & $\begin{array}{l}0.099 \pm 0.004 \\
0.096 \pm 0.009\end{array}$ \\
\hline $\begin{array}{l}\text { Type I, } \sigma^{\pi} \\
\text { Type II, } \delta\end{array}$ & $\begin{array}{r}32 \\
9\end{array}$ & $\begin{array}{l}48 \\
52\end{array}$ & $\begin{array}{l}13.6 \pm 1.7 \\
21.9 \pm 4.0\end{array}$ & 0.046 & $\begin{array}{l}0.103 \pm 0.004 \\
0.087 \pm 0.007\end{array}$ \\
\hline Non-diabetic & 22 & 43 & $12.6 \pm 1.4$ & & $0.056 \pm 0.002^{* *}$ \\
\hline $\begin{array}{l}\text { Non-diabetic, } \delta \\
\text { Non-diabetic, } \$\end{array}$ & $\begin{array}{r}9 \\
13\end{array}$ & $\begin{array}{l}45 \\
43\end{array}$ & $\begin{array}{l}13.5 \pm 2.3 \\
11.9 \pm 1.8\end{array}$ & $>0.05$ & $\overline{-}$ \\
\hline $\begin{array}{l}\text { Insulin, dose }<40 \text { units/day } \\
\text { Insulin, dose }>40 \text { units/day }\end{array}$ & $\begin{array}{l}27 \\
30\end{array}$ & $\begin{array}{l}42 \\
42\end{array}$ & $\begin{array}{l}10.1 \pm 2.0 \\
15.1 \pm 1.7\end{array}$ & 0.027 & $\begin{array}{l}0.099 \pm 0.021 \\
0.104 \pm 0.018\end{array}$ \\
\hline
\end{tabular}

*p calculated using the Mann-Whitney U test for comparing the ergothioneine values for different pairs of groups, except for non-diabetics for which the Student t-test was used.

** From 1.c. (20).

is no correlation with sex for the smaller non-diabetic population. When the diabetic population is separated into type I and type II and males are compared with females for each of these groups the sex difference is no longer statistically significant $(p>0.05)$. However, type II males have higher ergothioneine concentrations than type I males but this is not the case for type I vs type II females (tab. 1). There is no significant difference between diabetic vs non-diabetic males, diabetic vs non-diabetic females or type II diabetic males vs non-diabetic males $(p>0.05)$. Type II diabetics also have ergothioneine concentrations which are higher than those of type I diabetics (tab. 1). The $\mathrm{HbA}_{1}$ concentrations for all of the groups of diabetics are significantly above the average expected for normal individuals and by approximately the same amount (tab. 1). The data for the entire diabetic population were further analyzed by a least-squares linear regression analysis to find the correlation between ergothioneine concentrations and other variables (tab. 2). There was a weak correlation between ergothioneine concentrations and either insulin dose or age which showed some statistical significance. This was further analyzed by comparing different groups of subjects using the Mann-Whitney $U$ test. Diabetics below the age of 20 had lower ergothioneine concentrations than older diabetics although there was no significant difference among diabetics in the 20-40, $40-60$ and 60 and above age groups nor was there an age dependence for the smaller non-diabetic pop- ulation. All but one of the diabetics in the $0-20$ age group was a type I diabetic. We have already shown that type I diabetics have a lower ergothioneine concentration than type II diabetics (tab. 1). There is no statistically significant difference between type I diabetics below the age of 20 compared to type I diabetics above the age of 20 . Therefore, the correlation of ergothioneine concentration with age for diabetics is at least partially a consequence of the difference between type I and type II diabetics. Diabetics receiving less than 40 units of insulin per day had lower ergothioneine concentrations than those receiving larger insulin doses (tab. 1). The group receiving the lower insulin dose did not have a statistically significant difference in their mean $\mathrm{HbA}_{1}$ concentration, age or sex compared with the group receiving the higher insulin dosage (all are type I diabetics).

Tab. 2. Correlation of ergothioneine concentrations for the entire diabetic population and $\mathrm{HbA}_{1}$ concentration, insulin dose, years diabetic and age

\begin{tabular}{lrlc}
\hline Variable & $\mathrm{n}$ & $\begin{array}{l}\text { Correlation } \\
\text { coefficient }\end{array}$ & $\mathrm{p}$ \\
\hline HbA $_{1}$ & 113 & 0.1 & $>0.05$ \\
Insulin dose* & 57 & 0.27 & 0.043 \\
Years diabetic & 75 & 0.02 & $>0.05$ \\
Age & 100 & 0.20 & 0.048 \\
\hline
\end{tabular}

* Type I diabetics only. 


\section{Discussion}

The average ergothioneine concentrations measured by HPLC are generally lower than those reported by Fraser (4). This is probably due to the lower specificity of the colorimetric procedure (1) used in the previous work (4). Nevertheless, some of our general conclusions confirm the work of Fraser in that there is a significant fraction of diabetics whose ergothioneine concentrations are higher than the modal value (fig. 1). We can further specify that among diabetics, males, type II diabetics and diabetics taking a higher insulin dose have higher ergothioneine concentrations than their diabetic counterparts, i.e. females, type I diabetics and diabetics taking a lower insulin dose. It is possible that the management of diabetics with high ergothioneine concentrations could be aided with the administration of dietary zinc (10). Zinc is important for the storage of insulin and for the metabolism of arachidonic acid. Zinc insufficiency can lead to glucose intolerance. Since ergothioneine binds zinc, it can limit the availability of this cation and thereby aggravate the diabetic state. This situation would occur only in those diabetics with markedly elevated concentrations of ergothioneine: For patients in this group, zinc therapy may have some efficacy.

\section{Acknowledgement}

We are grateful to Dr. W. B. Spaulding of the Diabetic Day Care Centre at the McMaster University Health Sciences Centre for his cooperation with this project and for helpful discussions. We are also grateful to Dr. C. W. Dunnett of the Department of Clinical Epidemiology and Biostatistics for his assistance with the statistical analysis and to Mr. Alan Stäford for his assistance with the operation of the HPLC. This work was supported by grant A9848 from the Natural Sciences and Engineering Research Council of Canada.

\section{References}

1. Melville, D. B. (1959) Vitam. Horm. (New York) 17, 155204.

2. Mayumi, T., Kawano, H., Sakamoto, Y., Suehisa, E., Kawai, Y. \& Hama, T. (1978) Chem. Pharm. Bull. 26, 37723778.

3. Kawano, H., Otani, M., Takeyama, K., Kawai, Y., Mayumi, T. \& Hama, T. (1982) Chem. Pharm. Bull. 30, 17601765.

4. Fraser, R. (1950) J. Lab. Clin. Med. 35, 960-967.

5. Beatty, C. H. (1952) J. Biol. Chem. 199, 553.

6. Shukla, Y., Kulshrestha, O. P. \& Khuteta, K. P. (1981) Indian J. Med. Res. 73, 472-473.

7. Brummel, M. C. (1985) Med. Hypoth. 18, 351-370.

8. Hanlon, D. P. (1971) J. Med. Chem. 14, 1084-1087.

9. Reid, R. S. \& Rabenstein, D. L. (1982) J. Amer. Chem. Soc. $104,6733-6737$.

10. Epand, R. M. (1982) Med. Hypoth. 9, 207-213.

11. Begin-Heick, N., Dalpe-Scott, M., Rowe, J. \& Heick, H. M. C. (1985) Diabetes 34, 179-184.
12. Heyliger, C. E., Tahiliani, A. G. \& McNeill, J. H. (1985) Science 227, 1474-1477.

13. Williams, R. H. \& Berg, M. K. (1956) Proc. Soc. Exp. Biol. Med. 92, 20-23.

14. Nihei, T. \& Fraser, R. (1983) IRCS Med. Sci. 11, $1036=$ 1037.

15. Kawano, H., Murata, H., Iriguchi, S., Mayumi, T. \& Hama, T. (1983) Chem. Pharm. Bull. 31, 1682-1687.

16. Motohashi, N. \& Mori, I. (1983) Chem. Pharm. Bull. 31 , 1702-1707.

17. Kawano, H., Higuchi, F., Mayumi, T. \& Hama, T. (1982) Chem. Pharm. Bull. 30, 2611-2613.

18. Kawano, H., Cho, K., Haruna, Y., Kawai, Y., Mayumi, T. \& Hama, T. (1983) Chem. Pharm. Bull. 31, 1676-1681.

19. Mayumi, T., Okamoto, K., Yoshida, K., Kawai, Y., Kawano, H., Hama, T. \& Tanaka, K. (1982) Chem. Pharm. Bull. 30, $2141-2146$.

20. Abraham, E. C., Huff, T. A., Cope, N. D., Wilson, J. B., Jr., Bransome, E. D. \& Huisman, T. H. J. (1978) Diabetes $27,931-937$.
Richard M. Epand

Department of Biochemistry

McMaster University

1200 Main Street West

Hamilton, Ontario L8N $3 Z 5$

Canada 


\section{Peptides}

\section{Chemistry $\cdot$ Biology $\cdot$ Interactions with Proteins}

Proceedings of the 50th Anniversary

Symposium of the Nobel Prize

Albert Szent Györgyi

August 31 - September 4, 1987,

Szeged, Hungary

\section{Editors Botond Penke, Angela Török}

1988. $17 \mathrm{~cm} \times 24 \mathrm{~cm}$. XX, 467 pages. With numerous illustrations. Hardcover. DM 275,-, approx. US \$ 157.00 -ISBN 3110115468

Based on the presentation at an international meeting (the 50th Anniversary Symposium of the award of the Nobel Prize to Albert SzentGyörgyi), this volume compiles the knowledge accumulated in recent years, with new data on peptide synthesis, analysis and biology. The major objective of the book is to promote the interdisciplinary exchange of ideas and information between chemists, biochemists, physiologists and clinicians.

\section{From the Contents:}

In memoriam Albert Szent-Györgyi . Immunological Aspects of Peptides - Enzyme Substrates, Inhibitors and Toxins · Methods of Peptide Synthesis, Purification and Analysis - Molecular Mechanism of Hormone Action - Neuropeptides, Neurotransmitters and Behaviour - Peptides as Potential Drugs and Pharmaceuticals - Structure-Activity Relations - Structural and Conformational Considerations in the Design of Biologically Active Peptides - Participants - Authors' Index $\cdot$ Subject Index.

Price is subject to change without notice

\section{$W$
$\mathrm{DE}$
$\mathrm{G}$}

\section{de Gruyter · Berlin - New York}

Genthiner Straße 13, D-1000 Berlin 30, Phone: (030) $26005-0$ 200 Saw Mill River Road; Hawthorne, N.Y. 10532, Tel.: (914) 747-0110

\section{Gewinmen Sie mif den PHON-[ilastase-Assays den Methlouf gegen die Zeif}

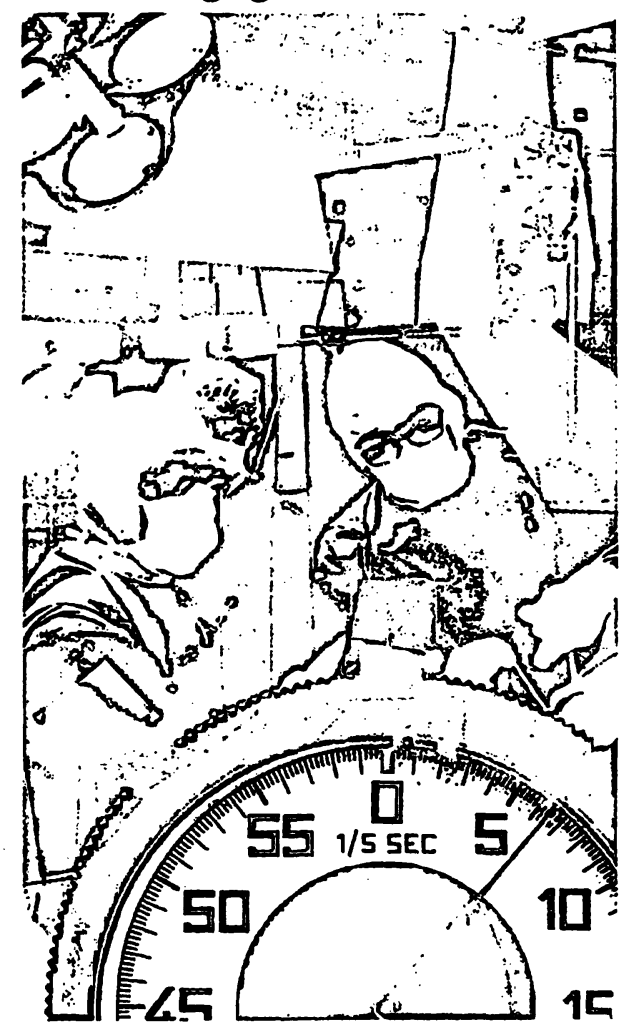

Die PMN-Elastase ist einer der sensitivsten Parameter zur Diagnose einer Entzündung. Die bekannte $2 \mathrm{~h}$-Version ermöglicht die Bestimmung aus Plasma, Stenalmark- und Synovialflüssigkeit und weiterem Untersuchungsmaterial. Ab Oktober 1988 steht der homogene Enzymimmunoassay PMN-Elastase IMAC zur Verfügung, er liefert aus dem Plasma innerhalb von 10 Minuten, bei manueller Methode innerhalb von 20 Minuten, die Entscheidungshilfe für den Kliniker.
DIAGNOSTICA MERCK

E. Merck

Frankfurter Straße 250

D-6100 Darmstadt 1 


\section{New Journal}

\section{Jouririag of}

Tirace Ellenenents and

Ellectrollyies in

HHeallth and Disease

\section{Analytical Methods \\ Metabolism: Biochemistry Pathobiochemistry \\ Nutrition $\cdot$ Toxicology $\cdot$ Epidemiology Clinical Application: Diagnosis Therapy}

\section{Editors-in-Chief}

Peter Brätter, Berlin, F. R. G.

Jürgen D. Kruse-Jarres, Stuttgart, F. R. G.

Ingrid Lombeck, Düsseldorf, F. R. G.

\section{Editorial Board}

P. J. Aggett, Great Britain - M. Anke, G. D. R.

G. M. Berlyne, U. S. A. · H. Bowen, Great Britain - J. L. Burguera, Venezuela

J. J. Canary, U. S. A. · J. H. J. Copius Peereboom, The Netherlands

D. M. Danks, Australia · G. S. Fell, Great Britain

L. E. Feinendegen, F. R. G. · W. Fresenius, F. R. G. - M. H. N. Golden, Jamaica

T. Günther, F. R. G. · K. M. Hambidge, U. S. A. · H.-J. Holtmeier, F. R. G.

M. Kirchgeßner, F. R. G. · B. Lönnerdal, U. S. A. · F. Manz, F. R. G.

O. Oster, F. R. G. · R. M. Parr, Austria · E. Sabbioni, Italy

P. Schramel, F. R. G. · F. W. Sunderman Jr, U. S. A. · Y. Tanaka, Canada

Y. Thomassen, Norway · G. Tölg, F. R. G. · J. Versieck, Belgium

A. Wendel, F. R. G. · G. L. Xu, China, G. Q. Yang, China · B. Zachara, Poland

\section{Subscription Information}

The first volume consists of 122 pages published in two issues in September and December 1987.

Subsequent volumes will comprise four issues with approx. 260 pages per calendar year.

1987: DM 140,-; approx. US $\$ 83.00 \cdot 1988$ : DM 280,-; approx. US $\$ 165.00$

Single issues are available at DM $80,-;$ approx. US $\$ 47.00$

Free sample copies available on request.

US dollar prices are subject to change without notice

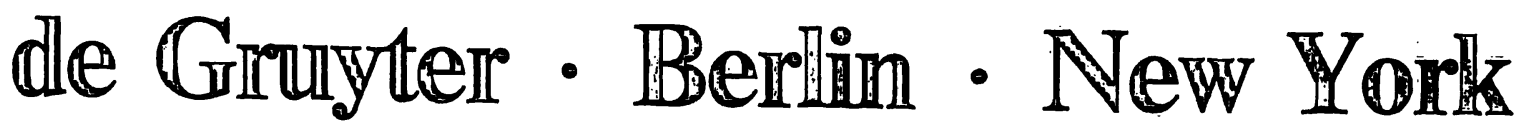

Genthiner Strasse 13, D-1000 Berlin 30 . Tel.: (030) 26005-0 . Telex 184027 . Telefax (0 30) 260 05-251 200 Saw Mill River Road, Hawthorne, N.Y. 10532 - Tel.: (914) 747-0110 · Telex 646677 - Telefax (914) 747-1326 